\title{
The Effect of Forward-Leaning and Pursed Lips Breathing Exercises on The Value of Oxygen Saturation in Adult Smokers
}

\author{
Muhammad Nurul Amin ${ }^{1 *}$, Erna Setiawati ${ }^{2}$, Rahmi Isma AP ${ }^{2}$, Meita Hendrianingtyas ${ }^{3}$ \\ ${ }^{1}$ Medical Faculty, Diponegoro University, Indonesia \\ ${ }^{2}$ Teaching Staff, Physical Medicine and Rehabilitation, Faculty of Medicine, Diponegoro University, Semarang, \\ Indonesia \\ ${ }^{3}$ Teaching Staff, Clinical Pathology, Faculty of Medicine, Diponegoro University, Semarang, Indonesia
}

\section{Keywords: \\ Cigarettes \\ Forward-leaning \\ Oxygen saturation \\ PLB (pursed lips \\ breathing)}

*) Correspondence to: muhammadnurulamin29

@gmail.com

Article history:

Received 30-05-2020

Accepted $25-06-2020$

Availableonline $01-07-2020$

\begin{abstract}
Background: Smoking which is a lifestyle trend continues to increase and take its toll each year. Cigarettes have chemical compounds, which has toxic and carcinogenic effects that can cause respiratory, cardiovascular, and other irritants. This can affect the distribution of oxygen to the body tissues. Forward-leaning and PLB exercises can help maximize breathing, thereby improving tissue oxygen distribution.

Objective: To determine the differences in oxygen saturation of adult smokers before and after practice forward-leaning and pursed lips breathing.

Methods: This study used a quasi-experimental method with two groups pre-post test design. The research subjects were 20 male respondents, the place of implementation at the Faculty of Medicine, Diponegoro University, Semarang. Research procedures included CKD and PLB exercises in the respondent group.

Results: An analysis using the Wilcoxon test obtained significant results, with $\mathrm{p}$ values $<0.05$ on acute and chronic effects after CKD and PLB exercises were performed on 20 respondents

Conclusion: A significant result in the oxygen saturation value of the group with PLB and CKD treatment with the PLB group before and after exercise on acute and chronic effects in adult smokers
\end{abstract}

DIMJ, 2020, 1(1), 26-29 DOI: https:// doi.org/10.14710/dimj.v1i1.7940

\section{Introduction}

Smoking behaviour has changed into lifestyle trends in various circles of society, both in the strata of high, medium and low economic classes. According to the World Health Organization (WHO), more than 7 million people die annually from smoking and 6 million of them are active smokers, out of at least 1.1 billion active smokers in the world. ${ }^{1,2}$ Cigarettes themselves have a variety of chemicals, at least the researchers estimate that smoking has 7,357 chemical compounds from various classes. These various compounds have toxic and carcinogenic effects that have the potential to cause respiratory, cardiovascular, malignancy and others. These compounds such as arsenic, acrolein, carbon monoxide, and others. ${ }^{3}$

Carbon monoxide (CO) contained in cigarettes is one of the ingredients that can affect the distribution of oxygen to body tissues. Carbon dioxide has a higher affinity of up to 250 times compared with oxygen to haemoglobin, haemoglobin that should bind with oxygen to form oxyhaemoglobin fails to bind to form carboxyhaemoglobin bonds that can interfere with the distribution of tissue oxygen and decrease oxygen saturation. ${ }^{3,4}$

The pursed lips breathing pattern is an exercise to regulate the breathing pattern and frequency to reduce air trapping, improve alveolar ventilation to improve gas exchange without increasing breathing work, regulate breathing speed so that breathing is more effective and reduce tightness. ${ }^{5}$ Forwardleaning position can increase the ability of the external diaphragm and intercostal muscles which 
are inspiring muscles. Optimization of these muscles can increase the volume of air going in and out. So that the combination of forward-leaning and PLB exercises in smokers can optimize inspiration and expiration, reduce muscle load and increase gas exchange. ${ }^{5,6}$ This study aims to determine the impact of forward-leaning exercises and pursed lips are breathing on oxygen saturation values in adult smokers at the Faculty of Medicine, Diponegoro University Semarang.

\section{Methods}

This research is an experimental test using a quasi-experimental study with two group pre-post test designs, with measurements before and after the intervention. This research was conducted from April to November 2019 at the Faculty of Medicine, Diponegoro University. The scope of this research covers the fields of physical medicine and rehabilitation.

The subjects of this study are adult smokers who are in the Faculty of Medicine, Diponegoro University, who have met the inclusion and exclusion criteria. Research subjects who are willing to take part in the research will be doing forward-leaning and PLB positions 3 times each week for 4 weeks or 12 exercises. Subjects would be excluded if they had exclusion criteria or were not willing to participate in the study with a presence of $<75 \%$.

The sample size used in this study was 24 adult smokers, using purposive sampling with predetermined criteria. The independent variable includes forward-leaning exercises and pursed lips breathing, and the dependent variable includes oxygen saturation values. Analysis of research data using the Shapiro-Wilk test for data normality. The next analysis uses the Wilcoxon test because the data obtained were not normally distributed in each group. The Mann-Whitney test was performed to compare oxygen saturation delta values in the PLB and forward-leaning groups with the PLB group because the data were not normally distributed. ${ }^{7}$

\section{Results}

This research was conducted on adult smokers in FK UNDIP Semarang from April to September 2019 a total of 26 people. There are 6 research subjects did not follow the study until completion so that the final total was 20 people. The characteristics of research subjects can be seen in the Table 1 .

Table 1. General characteristic subject

\begin{tabular}{lll}
\hline Characteristics & $\begin{array}{l}\text { Median }(\text { min } ~ \\
\text { max) }\end{array}$ & Rerata \pm SB \\
\hline Age (years) & $20,50(19-44)$ & $21,60 \pm 5,54$ \\
& & \\
Height $(\mathrm{Cm})$ & $\begin{array}{l}167,50(156- \\
180)\end{array}$ & $167,75 \pm 5,54$ \\
Weight $(\mathrm{Kg})$ & $60(45-77)$ & $59,30 \pm 7,08$ \\
& & \\
BMI $\left(\mathrm{kg} / \mathrm{m}^{2}\right)$ & $20,43(18,49-$ & $21,03 \pm 1,8$ \\
& $24,52)$ & \\
\hline
\end{tabular}

The acute effect of PLB and Forward Leaning exercises on oxygen saturation values

Wilcoxon test results for observing changes in oxygen saturation values before and after PLB and forward-leaning exercises on acute effects can be seen in Table 2.

Table 2. Oxygen saturation values before and after exercise on acute effects

\begin{tabular}{|c|c|c|c|c|c|}
\hline \multirow[t]{2}{*}{ Group } & \multicolumn{2}{|c|}{ Pre } & \multicolumn{2}{|c|}{ Post } & $p$ \\
\hline & $\begin{array}{l}\text { Median (min- } \\
\text { max) }\end{array}$ & Mean \pm SD & $\begin{array}{l}\text { Median (min- } \\
\text { max) }\end{array}$ & Mean \pm SD & \\
\hline $\begin{array}{l}\text { Pursed lips breathing } \\
\text { and forward-leaning }\end{array}$ & $\begin{array}{c}97,00(96,00- \\
98,00)\end{array}$ & $96,90 \pm 0,56$ & $\begin{array}{c}98,00(97,00- \\
99,00)\end{array}$ & $98,20 \pm 0,63$ & 0,006 \\
\hline Pursed lips breathing & $\begin{array}{c}97,00(97,00- \\
98,00)\end{array}$ & $97,40 \pm 0,51$ & $\begin{array}{c}99,00(98,00- \\
99,00)\end{array}$ & $98,60 \pm 0,51$ & 0,003 \\
\hline
\end{tabular}

*Wilcoxon test

The chronic effect of PLB and Forward Leaning exercises on oxygen saturation values

The results of measurements of changes in oxygen saturation values before and after 12 times the PLB and forward-leaning exercises on chronic effects, can be seen in Table 3. 
Table 3. Oxygen saturation values before and after exercise on chronic effects

\begin{tabular}{lccccc}
\hline Groups & \multicolumn{2}{c}{ Pre } & \multicolumn{2}{c}{ Post } & P \\
\cline { 2 - 5 } & $\begin{array}{c}\text { Median (min } \\
- \text { max) }\end{array}$ & Mean \pm SD & $\begin{array}{c}\text { Median (min- } \\
\text { max) }\end{array}$ & Mean \pm SD & \\
\hline Pursed lips breathing & $97,00(96,00-$ & $96,90 \pm 0,73$ & $99,00(98,00-$ & $98,60 \pm 0,51$ & 0,006 \\
and forward-leaning & $98,00)$ & & $99,00)$ & & \\
Pursed lips breathing & $97,00(96,00-$ & $97,00 \pm 0,47$ & $99,00(98,00-$ & $98,70 \pm 0,48$ & 0,004 \\
& $98,00)$ & & $99,00)$ & & \\
\hline
\end{tabular}

\section{*Wilcoxon test}

Oxygen saturation delta data that have been obtained from measurements performed normality test using the Shapiro-Wilk test. This data analysis was then used to compare the oxygen saturation delta values between the PLB and forward-leaning groups with the PLB group on acute and chronic effects. Shapiro-Wilk test results showed a p-value of 0,000 in the group with acute and chronic effects. This shows the data are not normally distributed in both then the Mann-Whitney test can be seen in Table 4 and Table 5.

Table 4.Differences in oxygen saturation delta values on acute effects

\begin{tabular}{lcc}
\hline Groups & Mean \pm SD & $\boldsymbol{p}$ \\
\hline $\begin{array}{l}\text { Pursed lips breathing and } \\
\text { forward-leaning }\end{array}$ & $1,3 \pm 0,82$ & 0,895 \\
Pursed lips breathing & $1,3 \pm 0.48$ & \\
\hline
\end{tabular}

Table 5. Differences in oxygen saturation delta values on chronic effects

\begin{tabular}{lcc}
\hline Groups & Mean \pm SD & $\boldsymbol{p}$ \\
\hline $\begin{array}{l}\text { Pursed lips breathing and } \\
\text { forward-leaning }\end{array}$ & $1,7 \pm 0,82$ & 0,552 \\
Pursed lips breathing & $1,8 \pm 0.42$ & \\
\hline
\end{tabular}

From the table shows that the p-value is not significant on the acute effect of 0.895 and the chronic effect of 0.552 .

\section{Discussion}

This study aims to prove the differences in oxygen saturation values before and after the administration of PLB and forward-leaning exercise training in adult smokers. The results of this study indicate that an increase in oxygen saturation after PLB and forward-leaning exercises in both acute and chronic effects. This is evidenced by the increase in oxygen saturation after exercise, for the acute effect of the mean value of $97.40 \pm 0.51$ to $98.60 \pm 0.51$ in group 1 and the mean value of $96.90 \pm 0.56$ to 98.20 \pm 0.63 in group 2 and for the chronic effect of the mean value of $97.00 \pm 0.47$ to $98.70 \pm 0.48$ in group 1 and the mean value of $96.90 \pm 0.73$ to $98.60 \pm 0.51$ at group 2.
The results of this study are in line with the research hypothesis, which states that there are significant differences in oxygen saturation values before and after PLB and forward-leaning exercises in adult smokers. These results are also in line with previous studies conducted by Ingrid Loka. T et al34 (2016) regarding differences in oxygen saturation values in tuberculosis patients given PLB training, in this study, it was said that there were significant differences in the treatment group before and after the intervention with p-values of 0,000 . The analysis proves that pursed lips breathing exercises have a significant impact on the intervention group.

The pursed lips breathing exercise is a breathing exercise that consists of two mechanisms: healthy inspiration and extended active expiration. The pursed lips breathing technique involves involuntary maximal expiration, which increases the strength of intra-abdominal muscle contraction so that the intraabdominal pressure increases. Increased intraabdominal pressure will trigger the movement of the diaphragm upward so that the piston cavity gets smaller, causing intra-alveolar pressure to increase so that it exceeds atmospheric air pressure, this condition makes airflow out of the lungs so that it can optimize breathing in smokers and COPD sufferers. ${ }^{5,6}$ Prolonged expiration on PLB breathing will also help eliminate airway obstruction which often occurs in people with COPD and people who consume cigarettes regularly so that respiratory resistance decreases. Decreased respiratory resistance will facilitate the exhaled air. PLB training by extending expiration will prevent air trapping, thereby avoiding lung collapse. ${ }^{6,8}$

The forward-leaning exercise position will help increase the diaphragm and external intercostal muscles in a leaning position of approximately 45 degrees. The diaphragm and intercostal muscles are the main inspiration muscles, at a 45 degree forwardleaning position making the gravitational force acting on these muscles more maximal than the sitting position. ${ }^{9}$ The gravitational force acting on the diaphragm muscle makes it easy for the muscles to move downward increasing the volume of the piston cavity by increasing its vertical length. The external 
intercostal muscles that are affected by gravity make it easier for the ribs to rise upward, thereby increasing the anteroposterior dimension. This exercise will also help intra-abdominal muscle contractions during the process of expiration, this increase in intra-abdominal pressure will push the diaphragm upward, thereby reducing the piston cavity. The smaller piston cavity size makes intra-alveolar pressure increases beyond atmospheric pressure causing air to flow out of the lungs thus improving the ventilation process. ${ }^{6,9}$

\section{Conclusion}

Based on the analysis of research data, it can be concluded that:

1. There is a significant difference in oxygen saturation values before and after doing forwardleaning and PLB exercises (acute effects) in adult smokers

2. There is a significant difference in oxygen saturation values before and after PLB exercises (acute effects) in adult smokers

3. There are significant differences in oxygen saturation values before and after forward-leaning and PLB exercises (chronic effects) in adult smokers 4. There is a significant difference in oxygen saturation values before and after PLB exercise (chronic effects) in adult smokers

5. There was no significant difference in the mean oxygen saturation delta values between groups 1 and 2 after exercise on acute effects

6. There was no significant difference in the mean oxygen saturation delta values between groups 1 and 2 after exercise on the chronic effect.

\section{Ethical Approval}

Ethical clearance was obtained from Research Ethics Commission Medical Faculty Diponegoro University with the number of 413/EC/KEPK/FK UNDIP/IX/2019.

\section{Conflicts of Interest}

The authors declare no conflict of interest.

\section{Funding}

No specific funding was provided for this article.

\section{Author Contributions}

Writing-original draft preparation, Muhammad Nurul Amin; writing-review and editing, dr. Erna Setiawati,Sp.KFR,MSi.Med

\section{Acknowledgments}

This work was supported by Department of Physical Medicine and Rehabilitation, Faculty of
Medicine, Diponegoro University, Semarang, Indonesia.

\section{References}

[1] World Health Organization (WHO). Who Report On The Global Tobacco Epidemic, 2017. World Health Organization. 2017. 1-263 p.

[2] Depkes. Pusat Data dan Informasi Kementerian Kesehatan RI. Perilaku Masyarakat Merokok di Indonesia. 2014.

[3] Rodgman A, Perfetti T. The Chemical Components of Tobacco and Tobacco Smoke, Second Edition. 2013.

[4] Ozdal M et al. Effect of Smoking on Oxygen Saturation in Healthy Sedentary Men and Women. Med Sci Monit. 2017;6:178-82.

[5] Guyton, A. C., Hall, J. E. Buku Ajar Fisiologi Kedokteran. Edisi 12. Jakarta : EGC. 2014

[6] Pamungkas R, Arif S. Efektivitas Pursed Lip Breathing Dan Deep Breathing Terhadap Penurunan Frekuensi Pernafasan Penyakit Paru Obstruktif Kronik (PPOK). STIKES Telogorejo Semarang. 2016. :1-7.

[7] Ismael $\mathrm{S}$ sastroasmoro S. Dasar-dasar Metodologi Penelitian Klinis 4th. jakarta: sagung seto; 2011. hal.207

[8] Sherwood, L. Fisiologi manusia dari sel ke sistem. Edisi 8. Jakarta: EGC. 2014. 506-10 p.

[9] Khasanah S, Maryoto M. Efektifitas Posisi Condong Ke Depan (forward-leaning) Dan Pursed Lips Breathing (PLB) Terhadap Peningkatan Saturasi Oksigen Pasien Penyakit Paru Obstruktif Kronik (PPOK). Pros Semin Nas Int. 2014. 